\title{
Assault and self-harm injuries: pattern, severity and etiology of injuries in victims attending emergency department of teaching hospital in central India
}

\author{
Manish Swarnkar*, Gaurav Pal, Subham Lilhare
}

Department of General Surgery, Jawaharlal Nehru Medical College, Sawangi (m), Wardha, Maharashtra, India

Received: 18 June 2016

Accepted: 15 July 2016

\author{
*Correspondence: \\ Dr. Manish Swarnkar, \\ E-mail: mswarnkar1971@gmail.com
}

Copyright: $($ the author(s), publisher and licensee Medip Academy. This is an open-access article distributed under the terms of the Creative Commons Attribution Non-Commercial License, which permits unrestricted non-commercial use, distribution, and reproduction in any medium, provided the original work is properly cited.

\begin{abstract}
Background: Intentional injury, including interpersonal violence and self-harm, is one of the world's leading causes of preventable injury. In India self-harm injuries, tops the list as a cause of mortality in 15-24 years age group, placing heavy burden on health care facilities. We examined violent injuries treated in the emergency department (ED) of our hospital to describe the epidemiology of assault and self-harm injuries.

Methods: Prospective data of 259 violence related injuries was collected who presented or received care from the ED of Hospital. Information about individual demographics; mechanism, nature, place, and activity of injury; injury types, and body regions affected; and discharge state were compared for assault and self-harm injuries.

Results: Of the 259 patients treated for violence-related injuries, $85.3 \%$ were of assault and $14.7 \%$ for self-harm injuries. The majority of patients were between the ages of 15 and 34. Male predominance (77.8\%) seen in assault cases, while female predominance seen in self-harm injuries. Alcohol intoxication was found in majority of victim and assailant as a provocating factor. Struck by or against was the most common mechanism of injury in assault cases while cutting/piercing in self-harm injuries. Soft tissue injuries predominate in both groups.

Conclusions: Assault and Self- Harm injuries are dominant cause of morbidity and mortality in young adults leading to loss of productive lives. Interventions that focus on detection and treatment of psychological illness, reduction of alcohol use and associated aggression, and family and intimate partner violence are suggested as priorities.
\end{abstract}

Keywords: Assault, Self-harm injuries, Emergency department, Soft tissue injury, Violence

\section{INTRODUCTION}

Violence is a leading cause of preventable injury worldwide. $^{1-4}$ Injuries accounted for $10.1 \%$ of the global burden of disease in $2013 .^{5}$ The proportion of disabilityadjusted life years (DALYs) due to disability (YLD) is much higher for collective violence $(69.1 \%)$.The main contributors to injury DALYs are road injuries (29.3\%), self-harm $(14.0 \%)$, and interpersonal violence $(8.4 \%){ }^{5}$ Self-harm is the second leading cause of death from injury and it is a main contributor to injury DALYs, over the period 1950-1995 the global self-harm death rates were reported by WHO to have increased. ${ }^{5}$ According to the global burden of disease study 2010-profile -India self-harm injuries raised to $8^{\text {th }}$ leading cause of premature death. ${ }^{6}$ Violence has physical, psychological, social and economic impacts. The economic costs of violence include the costs of medical and legal services, loss of earning and productivity and reduced quality life. The magnitude of health consequences of assaultive violence and its psycho-social and economic squeal indicates the need for effective preventive strategies. Accurate 
surveillance data are a critical component of a successful public health prevention campaign, but our country lacks data to describe medically treated violent injuries as it does not have a standard surveillance system to describe the incidence, nature, and characteristics of those injuries. This study presents the results from a pilot initiative of emergency department (ED) data on traumatic injuries. This analysis focuses on violence-related injuries with the objective of describing their nature and circumstances, defined as 'a deliberate incident with the intent to cause harm, injury or death, in which physical or other force was used (or threatened to be used) against oneself or another person and which led to injury'.

\section{METHODS}

This cross - sectional study included 259 consecutive assault victims who attended casualty department of Shyam Shah medical college and associated hospital, Rewa from June 2000 to July 2001 after getting approval from institutional ethical committee. Data was collected by trained interviewers, who were usually post-graduate resident in the hospital. Information relating to victim's age, gender and occupation were recorded, with details of weapons allegedly used, numbers of blows sustained and whether the victim fell to the ground. All injuries were charted on a standard proforma, and classified as hematomas, lacerations or fractures. Intra-oral lacerations were included except where these were associated with underlying jaw fractures involving the attached alveolar mucosa or hard palate. Weapons were classified as blunt, sharp, broken glass, fist, feet, firearm or 'other'. An injury severity scale was formulated which took account of both number and type of injuries: category I: one laceration/incised wound or one hematoma, category II: multiple soft tissue injuries category III: one fracture category IV: one fracture and soft tissue injury elsewhere category V: multiple fractures. Descriptive statistics to compare patients that have suffered a violence-related injury were calculated and compared using $\chi^{2}$-tests for categorical variables and t-tests for continuous variables.

\section{RESULTS}

Among the 259 violence related injury presented in ED $85.3 \%$ of cases treated for assault related injuries and $14.7 \%$ cases for self-harm injuries. Male predominance was seen in assault cases (3.5:1) while self-harm injuries were predominantly seen in self-harm injuries (2.2:1). The sex distribution of assault and self-harm injuries was statistically significant ( $\mathrm{p}$ value $<0.05$ ). The maximum prevalence of cases of assault and self-harm injuries were seen in 15-24 years age group $(35.3 \%$ and $63 \%$ respectively, $\mathrm{p}$ value - 0.003) followed by 25-34 years age group (Table 1).

Urban population more affected than rural in our study, alcohol intoxication was present in significant number of cases in assault victims (33.9\%, p value-0.00001). Majority of assault (79.6\%) and self-harm (84.2\%) cases were unemployed. Most of the assault $(66.9 \%)$ and selfharm injuries $(52.6 \%)$ were took place between 4:00 pm to 12:00 am. in our study we found splurge of assault cases in summer $(61.5 \%)$ followed by winter $(32 \%)$. Assault cases were seen in more diverse setting than selfharm injuries ( $\mathrm{p}$ value -.00001). Majority of assault cases occurred on streets $(35.3 \%)$ followed by farms $(27 \%)$ and home $(25.7 \%)$ while self-harm injuries were exclusively occurred at home $(92 \%)$ (Table 1).

Table 1: Demographic profile of victims.

\begin{tabular}{|c|c|c|c|}
\hline Characteristics & $\begin{array}{l}\text { Assault } \\
(\%) \\
(n=221)\end{array}$ & $\begin{array}{l}\text { Self-harm } \\
(\%) \\
(\mathbf{n}=\mathbf{3 8})\end{array}$ & $\begin{array}{l}\chi^{2}, \mathbf{p}- \\
\text { value }\end{array}$ \\
\hline \multicolumn{3}{|l|}{ Sex } & \multirow{3}{*}{$\begin{array}{l}33.7135 \\
<0.05\end{array}$} \\
\hline Male & $172(77.8)$ & $12(31.6)$ & \\
\hline Female & $49(22.2)$ & $26(68.4)$ & \\
\hline \multicolumn{3}{|l|}{ Age categories } & \multirow{6}{*}{$\begin{array}{l}15.98 \\
0.003039\end{array}$} \\
\hline $15-24$ & $78(35.3)$ & $24(63.2)$ & \\
\hline $25-34$ & $66(29.9)$ & $12(31.6)$ & \\
\hline $35-44$ & $46(20.8)$ & $02(5.2)$ & \\
\hline $45-54$ & $27(12.2)$ & 00 & \\
\hline$\geq 55$ & $04(1.8)$ & 00 & \\
\hline \multicolumn{3}{|l|}{ Habitat } & \multirow{3}{*}{$\begin{array}{l}4.6962, \\
0.030229\end{array}$} \\
\hline Rural & $91(41.2)$ & $08(21)$ & \\
\hline Urban & $130(58.8)$ & $28(79)$ & \\
\hline \multicolumn{3}{|l|}{ Employment } & \multirow{3}{*}{$\begin{array}{c}0.4287 \\
0.512628\end{array}$} \\
\hline Employed & $45(20.4)$ & $06(15.8)$ & \\
\hline Unemployed & $176(79.6)$ & $32(84.2)$ & \\
\hline \multicolumn{3}{|c|}{ Alcohol intoxication } & \multirow{4}{*}{$\begin{array}{l}77.6705 \\
0.00001\end{array}$} \\
\hline Yes & $75(33.9)$ & $02(5.3)$ & \\
\hline No & $49(22.2)$ & $36(94.7)$ & \\
\hline Unknown & $97(43.9)$ & 00 & \\
\hline \multicolumn{3}{|l|}{ Time of injury } & \multirow{4}{*}{$\begin{array}{c}2.9731 \\
0.226146\end{array}$} \\
\hline 8:00am-4:00pm & $51(23)$ & $13(34.2)$ & \\
\hline 4:00pm-12:00am & $148(67)$ & $20(52.6)$ & \\
\hline 12:00am-8:00am & $22(10)$ & $05(13.2)$ & \\
\hline \multicolumn{3}{|c|}{ Seasonal variation } & \multirow{4}{*}{$\begin{array}{l}16.0596, \\
0.000326\end{array}$} \\
\hline Summer & $136(61.5)$ & $16(42)$ & \\
\hline Rainy & $14(6.3)$ & $10(26)$ & \\
\hline winter & $71(32.2)$ & $12(32)$ & \\
\hline \multicolumn{3}{|c|}{ Place of occurrence } & \multirow{6}{*}{$\begin{array}{l}45.0158 \\
0.00001\end{array}$} \\
\hline Home & $78(35.3)$ & $35(92.1)$ & \\
\hline Farm & $57(25.8)$ & 00 & \\
\hline Street & $60(27.2)$ & 00 & \\
\hline $\begin{array}{l}\text { Industrial/constr } \\
\text { uction area }\end{array}$ & $11(4.9)$ & $02(5.3)$ & \\
\hline Recreational area & $15(6.8)$ & $01(2.6)$ & \\
\hline
\end{tabular}

The mechanism of injury was significantly different amongst assault and self-harm victims (p value-0.00001). struck by/or against an object $(80.5 \%)$ was the primary 
mode of injury in assault cases, cutting/piercing (42.1\%) and poisoning $(36.8 \%)$ was the primary mechanism seen in self-harm victims (Table 2).

Table 2: Distribution according to mechanism of injury.

\begin{tabular}{|c|c|c|c|}
\hline Variable & $\begin{array}{l}\text { Assault (\%) } \\
(n=221)\end{array}$ & $\begin{array}{l}\text { Self-harm } \\
(\%)(n=38)\end{array}$ & $\begin{array}{l}\chi^{2}, \mathbf{p}- \\
\text { value }\end{array}$ \\
\hline $\begin{array}{l}\text { Struck by/or } \\
\text { against }\end{array}$ & $178(80.5)$ & 00 & \multirow{6}{*}{$\begin{array}{l}157.270, \\
0.00001\end{array}$} \\
\hline Cut/pierce & $16(7.2)$ & $16(42.1)$ & \\
\hline Fall & $02(0.9)$ & 05 (13.2) & \\
\hline Suffocation & $03(1.4)$ & $03(7.9)$ & \\
\hline Poisoning & 00 & $14(36.8)$ & \\
\hline Unspecified & $02(0.9)$ & 00 & \\
\hline
\end{tabular}

Table 3: Profile of assailant in assault cases $(n=267)$.

\begin{tabular}{|ll|}
\hline Characteristic & Number $(\%)$ \\
\hline Sex & \\
\hline Male & $192(72)$ \\
\hline Female & $39(14.6)$ \\
\hline Unidentified & $36(13.4)$ \\
\hline Age group & \\
\hline $15-24$ & $113(42.3)$ \\
\hline $25-34$ & $96(36)$ \\
\hline $35-44$ & $32(12)$ \\
\hline $45-54$ & $08(3)$ \\
\hline$\geq 55$ & $03(1.1)$ \\
\hline Unknown & $15(5.6)$ \\
\hline Alcohol intoxication & \\
\hline Yes & $120(44.9)$ \\
\hline No & $99(37.1)$ \\
\hline Unknown & $48(18)$ \\
\hline
\end{tabular}

Among the assailants $72 \%$ were male and majority (78.3\%) belonged to $15-34$ years age group, $44.9 \%$ of assailants were intoxicated with alcohol at the time of violence (Table 3 ).

Soft tissue injuries (contusion abrasion, laceration/incised wounds, hematomas) were the most common type of injuries seen in both assault and self-harm victims. The body region affected by injuries were significantly different in two groups, head and face $(51 \%)$ were predominantly affected in assault cases followed by trunk and upper limb, self-harm injuries were most commonly seen over upper limb (45\%) (Table 4).

Blunt object i.e. lathi, rod hockey, bat was the most commonly $(47.5 \%)$ used weapon in assault cases followed by body parts (30\%). In $7.2 \%$ of cases weapon was unidentified (Table 5).
Table 4: Distribution according to type of injury and anatomic region affected ( $n=310$ injuries).

\begin{tabular}{|c|c|c|c|}
\hline Variable & $\begin{array}{l}\text { Assault } \\
(\%) \\
(n=279)\end{array}$ & $\begin{array}{l}\text { Self-harm } \\
(\%) \\
(\mathbf{n}=\mathbf{3 1})\end{array}$ & $\begin{array}{l}\chi^{2}, \mathbf{p}- \\
\text { value }\end{array}$ \\
\hline \multicolumn{3}{|l|}{ Type of injury } & \multirow{5}{*}{$\begin{array}{l}6.9422, \\
0.073762\end{array}$} \\
\hline Soft tissue injury & $219(78.5)$ & $21(67.7)$ & \\
\hline Bony injury & $41(14.7)$ & $04(13)$ & \\
\hline Head injury & $13(4.7)$ & $05(16.1)$ & \\
\hline Visceral injury & $06(2.1)$ & $01(3.2)$ & \\
\hline \multicolumn{3}{|l|}{ Body region } & \multirow{7}{*}{$\begin{array}{l}28.255 \\
0.00001\end{array}$} \\
\hline Head /face & $142(51)$ & $05(16.1)$ & \\
\hline Neck/throat & $08(2.9)$ & $03(9.8)$ & \\
\hline Trunk & $56(20.1)$ & $03(9.8)$ & \\
\hline Upper limb & $48(17)$ & $14(45)$ & \\
\hline Lower limb & $10(3.6)$ & $01(3.2)$ & \\
\hline Multiple injury & $15(5.4)$ & $05(16.1)$ & \\
\hline
\end{tabular}

Table 5: Type of weapon used in assault injuries.

\begin{tabular}{|ll|}
\hline Weapon & Number (\%) \\
\hline Blunt & $105(47.5)$ \\
\hline Sharp & $28(12.7)$ \\
\hline Fire arm & $08(3.6)$ \\
\hline Body part i.e. feet, fist & $64(30)$ \\
\hline Unidentified & $16(7.2)$ \\
\hline
\end{tabular}

Table 6: Severity of injury by weapon in assault injury $(n=213)$.

\begin{tabular}{|c|c|c|c|c|c|}
\hline Category & Blunt & Sharp & $\begin{array}{l}\text { Body } \\
\text { part }\end{array}$ & Unidentified & $\begin{array}{l}\text { Total } \\
(\%)\end{array}$ \\
\hline I & 71 & 16 & 36 & 04 & $127(59.6)$ \\
\hline II & 14 & 06 & 06 & 07 & $33(15.5)$ \\
\hline III & 04 & 02 & 01 & 01 & $08(3.8)$ \\
\hline IV & 07 & 03 & 17 & 01 & $28(13.1)$ \\
\hline V & 09 & 01 & 04 & 03 & $17(8)$ \\
\hline
\end{tabular}

$\chi 2=33.2942$. The $p$-value is .000871 . The result is significant at $\mathrm{p}<.05$.

Severity of injury in majority of assault cases (59.6\%) across all weapon groups falls in to category 1(minor injury). Severity of injury significantly increases when combination of body part (fists and feet) or blunt and sharp object together used. (p- value 0.00087) (Table 6).

Majority of assault cases were discharged from ED itself, $41 \%$ after treatment and $25 \%$ after assessment without any need of treatment. Nearly a quarter of cases were shifted to higher center to facilitate desired treatment only $10 \%$ of assault cases required admission with mean stay of $5.6 \pm 1.4$ days. But scenario amongst the self-harm victims were significantly different, $9.8 \%$ cases were died in ED or during transfer. More than three quarter was hospitalized and $50 \%$ had a hospital stay of $7 \pm 2.3$ days 
and $23.8 \%$ required hospital stay of more than two weeks.

\section{DISCUSSION}

In our study out of total 826 injury cases seen in ED, $31.3 \%$ of cases comprises of violence related injury thus placing a heavy burden on the health care system, and on individuals, families, and communities. Violence prevention is often focused on high-risk populations, which from these data include young adults and men. Education programs, restricting availability of alcohol, training health professionals to deal with interpersonal violence, development of support, and guidance groups, and prevention-oriented policies are recommended as successful or promising interventions. ${ }^{7}$ In assault cases male sex outnumbered female both as victim and assailant which is supported by the literature. ${ }^{8-10}$ Victims of assaults were frequently young adults, belonging to 15-34 years of age group which was expected and similar to other studies but it was surprising that in one year period in a busy accident and emergency department few elderly victims were seen. ${ }^{11,12}$ Which was contrary to concept is that the elderly are the most frequently attacked and suffer serious injuries. ${ }^{13}$ Self-harm injuries were predominantly seen in female sex $(68.4 \%)$ and 15 24 years of age group $(63.2 \%)$. Girls are more likely to internalize whereas boys are more likely to externalize suggest that girls may be more likely to hurt themselves intentionally when turning emotions inward. ${ }^{14,15}$ Feminist contributions to understanding self-harm have focused on the sociocultural construction of behavior and psychopathology in our society that limits opportunities and does not encourage girls and women to maintain "voice". ${ }^{16}$ according to report on causes of death in India, 2001-2003 in 15-24 of years age group, Intentional selfharm (suicide) accounting for every sixth death in this age group, tops the list. About $35 \%$ of the total suicidal deaths belong to this age group, with maximum proportion of $26 \%$ reported at ages 20 and $21 .^{17}$

There appeared to be positive correlation between unemployment of the victim and assault, unemployment may leads to the social deprivation lack of opportunity and poverty, frustration and aggressive behavior resulting in to violence. ${ }^{18}$ Alcohol consumption playing an important role in increasing aggression. ${ }^{19}$ The results in this study confirmed the link between assault and recent alcohol intake ( $p$-value $<0.00001$ ), One measure that seems to decrease the amount of alcohol consumed by a population is to increase the price. ${ }^{20}$ Other assaultprevention measures include raising the minimum legal drinking age to 21 , formal training of bar staff to avoid serving intoxicated customers and promotion of lowalcohol drinks. ${ }^{21}$ most of assault related cases occur during evening to mid night hours and in summer season due to increased activity and night life of population. ${ }^{21}$ Violence related injury most commonly occurs at home mainly due to family /interpersonal conflicts, property related disputes. ${ }^{11,12,21,22}$ In our study farm was the second most common site of assault related injuries particularly during crop harvesting season over crop and agricultural land related conflicts. Self-harm injuries were exclusively occurred at home $(92.1 \%){ }^{22}$ Struck by or against an object' was the primary mechanism for $80.5 \%$ of assaults, but was not a mechanism found among self-inflicted injuries. Cutting and piercing was the leading mechanism of self-harm injuries $(42.1 \%)$, followed by poisoning in $36.8 \%$ of cases which is supported by similar studie. ${ }^{23,24}$ Soft tissue injuries (contusion, bruise, abrasion, open wound) were the most frequent injuries in the self-harm group $(67.7 \%)$ and also the leading injury type among assault patients $(78.5 \%){ }^{12}$ The body region affected by the injury also differed significantly between the two groups: head and face injuries were dominant among assault victims $(51 \%)$, Upper extremities were the predominant localization of injuries in the self-harm group, $45 \%$. Assailant generally select most vital body parts which can be easily stroked and result in grievous injury. Oral and maxillofacial surgeons and/or plastic surgeons as well as accident and emergency staff are therefore likely to be involved in the management of assault victims. Uses of blunt objects were the commonest weapon of assault in this study followed by body parts. Comparison of injury and type of weapon showed that attacks with fists, or a combination of fists and feet, gave rise to fractures significantly more often compared with attacks with blunt weapons. This may reflect the greater momentum of fists and feet compared with most blunt objects. ${ }^{11}$

Violence and its consequences lead to severe injuries and put a heavy burden on health care. One out of every third patients who suffered violence related was treated in the ED or required admission to a hospital for further medical care. Furthermore, every sixth death in 15-24 years of age group due to self-harm injuries which puts this group at particularly high risk of severe injury and poor outcome and loss of young productive life. The average time of 5-7 days of hospitalization of the patients denotes serious injury and high medical care costs. In addition to the direct medical costs, these patients, primarily young adults, experience time away from productive work and family. It is also likely that longterm physical and psychological recovery could exceed the period of direct medical intervention.

\section{CONCLUSION}

Persons in the age group of 15-34 years were found to be more predisposed to violence. There is an urgent need to address the social and emotional needs of the adolescents and young adults. Prevention of assault might include modification of violent behavior, to resolve conflict as early as possible and legislation and codes of practice related to firearm and purchasing and consumption of alcohol should be implemented strictly. Self-harm is a maladaptive coping strategy means that both prevention 
and intervention efforts should be directed toward teaching and encouraging more positive and constructive coping and problem solving practices.

Funding: No funding sources Conflict of interest: None declared

Ethical approval: The study was approved by the institutional ethics committee

\section{REFERENCES}

1. Krug EG, Mercy JA, Dahlberg LL, Zwi AB. The world report on violence and health. The Lancet. 2002;360(9339):1083-8.

2. Krug EG, Sharma GK, Lozano R. The global burden of injuries. American journal of public health. 2000;90(4):523.

3. Organization WH. Global health risks: mortality and burden of disease attributable to selected major risks. World Health Organization; 2009. Available at

http://www.who.int/healthinfo/global_burden_disea se/GlobalHealthRisks_report_full.pdf.

4. Peek-Asa C, Hyder A. Injury prevention and control: the public health approach. Detels, R; Beaglehole, R; Lansang, MA, 2009. Available at http://oxfordmedicine.com/view/10.1093/med/9780 199218707.001.0001/med-9780199218707-chapter1004.

5. Haagsma JA, Graetz N, Bolliger I, Naghavi M, Higashi H, Mullany EC, et al. The global burden of injury: incidence, mortality, disability-adjusted life years and time trends from the Global Burden of Disease study 2013. Injury Prevention. 2016;22(1):3-18.

6. Gbd profile: India, global burden of diseases, injuries, and risk factors study, 2010. Available at www.healthdata.org/sites/default/.../ihme_gbd_coun try_report_india.pdf.

7. Wood S, Bellis M, Nurse J, Sirotkin M. A review of evidence for prevention, 2010. Available at http://www.cph.org.uk/wpcontent/uploads/2012/08/sports-injuries-a-reviewof-evidence-for-prevention.pdf.

8. Reilly J, Muldoon OT, Byrne C. Young men as victims and perpetrators of violence in Northern Ireland: a qualitative analysis. Journal of Social Issues. 2004;60(3):469-84.

9. Steen K, Hunskaar S. Violence in an urban community from the perspective of an accident and emergency department: a two-year prospective study. Medical Science Monitor. 2004;10(2):CR75CR9.

10. Kruse M, Sørensen J, Brønnum-Hansen H, HelwegLarsen K. Identifying victims of violence using register-based data. Scandinavian journal of public health. 2010;38(6):611-7.

11. Shepherd J, Scully C, Shapland M, Irish M, Leslie I. Assault: characteristics of victims attending an inner-city hospital. Injury. 1988;19(3):185-90.

12. Gal M, Rus D, Peek-Asa C, Cherecheş RM, Şirlincan EO, Boeriu C, et al. Epidemiology of assault and self-harm injuries treated in a large Romanian emergency department. European journal of emergency medicine: official journal of the European Society for Emergency Medicine. 2012;19(3):146.

13. Shukla RB. Violence and the elderly; a cause for concern. J Geriatr Med. 1985;6(1).

14. Crick NR, Zahn-Waxler C. The development of psychopathology in females and males: current progress and future challenges. Development and psychopathology. 2003;15(03):719-42.

15. Leadbeater BJ, Blatt SJ, Quinlan DM. Genderlinked vulnerabilities to depressive symptoms, stress, and problem behaviours in adolescents. Journal of Research on Adolescence. 1995;5(1):129.

16. Shaw SN. Shifting conversations on girls' and women's self-injury: an analysis of the clinical literature in historical context. Feminism and Psychology. 2002;12(2):191-219.

17. Report on causes of death in India, 2001-2003. Available at www.cghr.org/wordpress/wpcontent/.../Causes_of_death_2001-03.pdf.

18. Shepherd JP, Shapland M, Irish M, Scully C, Leslie I, Parsloe P. Assault rates and unemployment. The Lancet. 1986;328(8514):1038-9.

19. Wells S, Graham K. Aggression involving alcohol: relationship to drinking patterns and social context. Addiction. 2003;98(1):33-42.

20. Skinner H, Holt S, Sheu W, Israel Y. Clinical versus laboratory detection of alcohol abuse: the alcohol clinical index. $\mathrm{Br}$ Med J (Clin Res Ed). 1986;292(6537):1703-8.

21. Wright J, Kariya A. Assault patients attending a Scottish accident and emergency department. Journal of the Royal Society of Medicine. 1997;90(6):322-6.

22. Baruah A, Baruha A. Epidemiological study of violence: a study from North East India. Indian Journal of Community Medicine. 2007;32(2):137.

23. Laye-Gindhu A, Reichl KAS. Nonsuicidal self-harm among community adolescents: understanding the whats and whys of self-harm. Journal of Youth and Adolescence. 2005;34(5):447-57.

24. Garrison CZ, Addy CL, McKeown RE, Cuffe SP, Jackson KL, Waller JL. Non-suicidal physically self-damaging acts in adolescents. Journal of Child and Family Studies. 1993;2(4):339-52.

Cite this article as: Swarnkar M, Pal G, Lilhare S. Assault and self-harm injuries: pattern, severity and etiology of injuries in victims attending emergency department of teaching hospital in central India. Int Surg J 2016;3:1618-22. 